\title{
P̈̈̈KKIRJOITUS
}

\section{HYVÄT TIEDOT EIVÄT VIELÄ TAKAA}

\section{POLIITTISTA OSALLISTUMISTA}

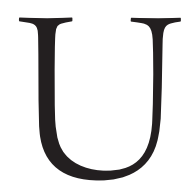

Tusimman International Civic and Citizenship Education Studyn (ICCS 2009, 30 maan vertailu) mukaan suomalaisnuorten yhteiskunnallinen tietämys on muiden maiden nuoriin verrattuna huippuluokkaa. Silti he eivät pidä sen enempää perinteisten poliittisten instituutioiden kuin yhteiskunnallisten liikkeiden kautta tapahtuvaa kansalaistoimintaa tärkeänä. Politiikka ja yhteiskunnalliset asiat kiinnostavat suomalaisia vähemmän kuin muita.

Politiikka olisi elvytettävä kouluissa - eikä vain demokratian ja osallistumisen opiskeluna kirjoista, vaan käytännön toimintana. On toki tärkeää tietää, miten lait säädetään, mutta koulussa olisi ennen kaikkea opittava osallistumaan ja pitämään sitä luontevana osana inhimillistä toimintaa. Peruskoulun lisäksi kansalaiskasvatus ja -osallistuminen olisi otettava vakavammin mukaan myös ammatilliseen koulutukseen. Aikuiskoulutuksella tuskin on merkittävästi osallistumista aktivoivaa vaikutusta, kun pohjatyöt nuorisoasteella on jätetty tekemättä.

YLEISEEN JA YHTÄLÄISEEN äänioikeuteen perustuva edustuksellinen demokratia on historiassa melko uusi asia. Käytännössä sitä on toteutettu meillä Suomessakin vasta sata vuotta. Jokainen ääni on yhtä painava. Mutta minkä painoinen se nykyään on? Tärkeitä yhteiskunnallisia ja laajoja väestöryhmiä koskettavia päätöksiä tehdään demokraattisen järjestelmän ulkopuolella. Siksi myös osallistuminen demokratiaan on menettänyt vetovoimaansa. Äänestämättömyys on reaktio vallan luisumiseen pois kansanvallan piiristä.

Se, että äänestämättömyys ja osallistumattomuus ovat yleisintä vähiten koulutettujen ja työttömien tai syrjäytyneiden keskuudessa, ei ole merkki tyytyväisyydestä. Se on pikemminkin ilmaus voimattomuudesta. Osallistuminen ei ole vain "itsestä kiinni". Helsingin yliopistossa viime vuonna tehdyn tutkimuksen (Ari Ruusulaakso) mukaan matala koulutustaso, nuori ikä, vuokralla asuminen ja pienet tulot ovat tekijöitä, jotka yhdistyneenä työttömyyteen passivoivat yksilöä niin poliittisesti kuin muutenkin. Työttömyyden pitkittyessä äänestämisen todennäköisyys vähenee ja passiivisuus lisääntyy. Vähäinen kansalaisosallistuminen ei ole yksilön ongelma, se on yhteiskunnallinen ongelma.

ICCS-tutkimuksen mukaan suomalaisnuoret luottavat poliittisiin puolueisiin selvästi vähemmän kuin muihin yhteiskunnallisiin instituutioihin, eivätkä he usko liittyvänsä aikuisina mihinkään puolueeseen. Nuoret seuraavat aikuisväestön mallia: vuoden 2009 European Values Surveyn mukaan suomalaisista vain $15 \%$ luotti poliittisiin puolueisiin. Eduskuntaan, 
maan hallitukseen ja Euroopan unioniin luotti noin $40 \%$ aikuisväestöstä.

HiljaTtAan ILMESTYNeEn Klassiset poliittiset ajattelijat -kirjan (Vastapaino) toimittajat Petri Koikkalainen ja Paul-Erik Korvela luonnehtivat nykyisyyttä aikakaudeksi, jolloin vallassa olevat yrittävät neutraloida, hallinnollistaa ja tieteellistää poliittiset kysymykset. Erityisesti taloustieteellinen puhetapa on työntänyt politiikkaa tieltään ja osin korvannutkin sen. Päätökset tehdään "Suomen ja kansakunnan parhaaksi" - vaikka sellaista yhtenäistä intressiryhmää kuin kansakunta tai Suomi ei ole olemassakaan.

Kansalaiset esitetään asiakkaina, joiden puolesta asiantuntijatietoon perustuvia rationaalisia päätöksiä tehdään. Politiikka on vain häiritsevä tekijä parhaan vaihtoehdon toteuttamiseksi. Esimerkkejä löytyy lähimenneisyydestäkin helposti. Valtioneuvoston "toimitusjohtajana” itseään pitänyt pääministeri Matti Vanhanen (Mies joka halusi olla asia) kielsi ministereitä puhumasta julkisuudessa hallituksessa valmisteltavista asioista, jotta niistä ei syntyisi "tarpeetonta keskustelua". Se, että teknokraattipoliitikot ajavat omaa politiikkaansa sanomalla, että "nyt ei pidä politisoida tätä asiaa", on karhunpalvelus demokratialle. Näin vallankahvassa olevat kieltävät politiikan: he esittävät, että politiikka on jotain likaista, jolla ei pidä sotkea "asioiden hoitamista kuntoon".

Tässä tullaan politiikan kriisissä tärkeään asiaan: vallassa olevat pitävät päämääriä annettuina, ja tehokkaimmat keinot niihin pääsemiseksi löytyvät asiantuntijatiedon perusteella. Tilanne on nurinkurinen. Ensin pitäisi päästä yksimielisyyteen siitä, mikä on se päämärär, jonka tavoittelemiseksi keinoja (eli politiikkavaihtoehtoja) puntaroidaan keskenään. Tuotetaanko mieluummin entistä kiiltävämpiä puhelimia vai parempia terveyspalveluja? Kumpi edistää paremmin hyvää elämää? Demokratiassa pitäisi ennen muuta ruokkia keskustelua päämääristä. Vasta sen jälkeen on mielekästä ottaa kantaa siihen, ovatko esimerkiksi talouskasvu ja kilpailukyky tavoittelemisen arvoisia välineitä näihin päämääriin pääsemiseksi.

Vaikuttaminen ei toki tyhjene äänestämiseen ja valtiolliseen päätöksentekoon. Siksi myös kansalaisten osallistumista parlamentaarisen järjestelmän ulkopuolella olisi aktivoitava. Osa nuorista on löytänyt uusia kansalaisvaikuttamisen kanavia. Laajetessaan ne voivat lisätä painetta myös parlamentaarisessa päätöksenteossa. Politiikan järjestys muuttuu: ensin pyritään vaikuttamaan ei-parlamentaarisessa kansalaistoiminnassa, ja vasta sen jälkeen asia saattaa nousta edustukselliselle tasolle.

EI RIITÄ, että ihmisille kaadetaan päähän kansalaistietoa. Tieto ilman motiivia ei muutu toimiksi. Vastaavasti harjoitellut toimet eivät muutu ilman toistuvaa tekemistä tottumukseksi. Koulut ja oppilaitokset on muutettava demokraattisen toiminnan ja osallistumisen areenoiksi. Vähemmän kokeisiin ja testeihin pänttäämistä, enemmän osallistuvaa toimintaa. Eikä tämäkään vielä riitä. Myös poliittisen kulttuurin on muututtava elämänmakuiseksi ja keskustelevaksi poliittiseksi. Hajuton, mauton ja vaihtoehdoton "asioiden hoitaminen" tukahduttaa koko demokraattisen järjestelmän.

Heikki Silvennoinen 